\title{
Introduction \\ Ten long years of crisis
}

\author{
Daniel Cohen*
}

\begin{abstract}
The crisis celebrates its tenth anniversary, offering economists a lesson in modesty and a great opportunity to take a new look at their understanding of the world. The effect of a zero lower bound on interest rates on the efficiency of economic policies, the Keynesian multiplier measure, the issue of the growth slowdown being a cause or consequence of the crisis, the effect of rising uncertainties on households' and firms' behaviour, the effectiveness of macro-prudential stabilisation, the impact of inequalities on the functioning of the credit market, the way in which the coordination of macro-economic policies in Europe is designed and promoted: all these crucial questions are part of the economists' research programme, and this special issue offers a rich review of the progress already achieved.
\end{abstract}

Keywords: financial crisis, European crisis, productivity, inequalities, uncertainty, employment adjustment, economic policies 
T en years long years have passed since the start of the crisis. A lot has been learned about its causes and consequences, but many factors remain mysterious. When the Queen of England had expressed her surprise that so few economists were able to predict it, she had been answered that it was because everyone was focused on managing their own risk, without anyone understanding that the threat was on the system as a whole. The securitisation of real estate investments at the origin of the crisis had certainly been analysed. What had obviously not been foreseen, in part because it was not visible, including to the regulators, was the extent to which the banks' off-balance sheet commitments were putting the whole system at risk.

When the crisis started, the comparison with the crash of 1929 appeared obvious. By some sort of intellectual miracle, the President of the U.S. Federal Reserve, Ben Bernanke, was its undisputed expert. He did everything possible to avoid the panic which followed in the 1930s, not hesitating to phenomenally increase the Central Bank's balance sheet. After the collapse of Lehman Brothers, a strategic error due, perhaps to the idea that the worst of the crisis was already over, the fall in industrial production and international trade reached almost $20 \%$ in less than nine months. It was then thought that the crash of 1929 was starting again. The collective response to the crisis, this time well aware of what was at stakes, met the challenges. Global fiscal stimulus, coordinated by the International Monetary Fund, ultra-accommodative monetary policy, like that conducted by Bernanke, and pursued in Europe, and strengthening of international cooperation, through the G20 in particular, all things which had failed in the thirties. And it worked. As early as in the second quarter of 2009, growth returned to the positive in France and in Germany. In the United States, the NBER believed that the crisis was over at the end of June 2009.

Unfortunately, when the crisis crossed the Atlantic, bringing down Greece, then Ireland and Portugal, the eurozone was not equal to the event, repeating, in this instance, the errors of the thirties: budgetary austerity too soon, monetary policy reluctant to come to the rescue of States threatened by a refinancing crisis. It would be necessary to wait for the famous speech by Mario Draghi on July 26 2012, announcing that he would do "whatever it takes" to save the eurozone, to get away from the sovereign debt crisis. When Mario Draghi made his speech, spreads on Italian and Spanish debt relative to Germany had already reached 536 and 638 basis points respectively! Although the restrictions coming from monetary policy were removed after this speech, the conduct of fiscal policy would remain, however, marked by a consolidation against the tide, playing an unquestionably pro-cyclical role over the entire eurozone. Ultimately, while the crisis had started in the United States, the rebound would happen much sooner in this country than in the eurozone.

Returning to the "systemic" causes of the crisis, the emphasis has rightly been put on the collective non-accountability of the international financial system. But other causes also played a decisive role upstream. The rise of inequality in the United States is one of them. The series constructed by Piketty, Saez and Zucman show a major stagnation of the income of the middle class over the past decades. This explains why borrowing, facilitated by the real estate bubble, has been the main way around this stagnation of purchasing power. 
It is well established in the literature that financial crises have lasting consequences on economic growth. The slowdown observed after the crisis is therefore not surprising. But a reverse causality is also possible, namely that the slowing down of long-term growth could actually be responsible for the crisis. This is the hypothesis made by Blanchard, Cerutti and Summers at an ECB conference organised in Sintra in 2015 (Blanchard et al., 2015). On the basis of the theories of Laurence Summers and Robert Gordon on secular stagnation, they suggested analysing the crisis as the indirect consequence of the latter. Showing that post-crisis growth rates have been getting lower and lower over the last fifty years, they concluded that households and firms have consistently overestimated their growth prospects and their own solvency, sooner or later fatally hitting the wall of refinancing their debt.

The article presented in this special issue by Gilbert Cette, Simon Corde and Rémy Lecat offers a thorough test of this thesis according to which the slowdown in growth preceded the crisis. Is there a break in the productivity trend in France, before, during or after the crisis? By focusing here on Total Factor Productivity, measured on the basis of macroeconomic data, the answer seems indisputably affirmative. Indeed, it is quite remarkable that its growth rate has been nil since 2003, well before the crisis began. It is not surprising in these conditions that gains in labour productivity have also collapsed, at a rate of $0.5 \%$ a year. It should be noted that the United States, were a rebound in labour productivity had been recorded in the 90s following the dissemination of ICTs, also experienced a significant decline in productivity since the early 2000s. The analysis of Cette et al. allows to go a step further in the explanation of this slowdown. They note that it is concomitant with an increase in inequalities between firms. The most efficient firms' productivity, which are not necessarily the same from one year to the next, remains on a sustained trend of increase. It is the gap between the best performances and the average which pulls the average down. Richard Freeman and his co-authors' work partly corroborates these results (Barth et al., 2016). Analysing wage inequalities in the United States, they had shown that they were almost completely explained by a widening of inequalities between companies, not within them... We must therefore seek to understand the unprecedented link between slowing growth and widening inequalities, which is one of the most active directions of research underway.

The effectiveness of economic policy is the other major question that the crisis brought back to the forefront of the intellectual debate. One of the cruel surprises of the period was to discover that the Keynesian multiplier was much higher than expected. While the traditional models simulated a multiplier in the range of 0.5, the raw empirical reality estimated by Blanchard and Leigh (2013) revealed much higher levels, as high as 1.5. It should be remembered that Eichengreen and his co-authors had established a multiplier as high as 2 for the crisis of 1929 (Almunia et al., 2010). Greece falls exactly into this pattern, with a budgetary consolidation of 12 points of GDP and a $25 \%$ cumulative loss in production.

Several factors explain why the multiplier was higher than expected. When the crisis is intense, the households with the most limited borrowing capacities will have more difficulty in smoothing out their consumption. The increase in income uncertainty is documented in the article by Pierre Pora and Lionel Wilner, who show that there is an important distinction to be made between the volume of hours worked by the poorest, and the hourly remuneration of the richest. A 
form of pessimism can also spread. As André Masson and Luc Arrondel also highlight in this issue, households' holdings in risky securities declined considerably after the crisis not because of a change in their intrinsic attitude toward risk, but, as the article shows, because the world appears more uncertain in the crisis.

The increase in the multiplier also owes a lot to the fact that monetary policy has lost in efficiency as a force to counterbalance fiscal consolidation. When inflation becomes too low, and interest rates drop close to the "zero lower bound", monetary policy meets limits that are difficult to get around. Ramey and Zubairy (2014) had shown that the budgetary multiplier was much higher when the interest rates are at the lower bound. The article by Jocelyn Boussard and Benoît Campagne in this issue takes up this theme. Budgetary consolidation in Europe took place in the worst possible conditions: it was conducted simultaneously in all eurozone countries, and under a fixed exchange rate regime that deprived the countries the most involved in the process of fiscal consolidation of the benefit of the safety valve that is the exchange rate. The fact that the eurozone's monetary policy has come up against the lower bound has limited its efficiency. The article also shows that at the lower bound on interest rates, the bigger the fiscal consolidation, the more its effect on economic activity (i.e. its multiplier effect) is recessive. An optimal coordinated fiscal policy, to follow this model, would have required a fiscal consolidation in the South of Europe and a stimulus in the North, whose absence heavily penalised the former.

The use of non-conventional policies was imposed upon central banks, in the United States as well as in Europe, to circumvent this obstacle of the lower bound on interest rates, and in the case of Europe, also to solve the sovereign debt crisis. The article by Désiré Kanga and Grégory Levieuge examines these policies, trying to distinguish their effects on the sovereign rates and on loans to the private sector. The paradox of the article is to show that non-conventional policies had more favourable effects in the countries that had the least need, Germany and Austria, than in the countries that should have been helped as a priority, Greece, Italy, Spain and Portugal. By expanding the class of assets eligible for refinancing, however, the ECB has supported the credit policy of commercial banks. According to the estimation of Jean Barthélémy, Vincent Bignon and Benoît Nguyen, the increase in the share of illiquid collateral has significantly helped to increase lending to the economy.

The crisis has also forced to rethink banking regulation. In Europe, the Basel 3 agreements sought to include off-balance sheet operations in prudential calculations for the first time. The banking industry was opposed to these measures on the grounds that they were going to impact the sector's profitability, and therefore have negative effects on credit supply. Using a new database, Olivier de Bandt, Boubacar Camara, Pierre Pessarossi and Martin Rose provide an answer to this: the increase in equity, according to this study, is in no way detrimental to the sector's profitability. Hence the argument that the banking system should be protected from does not hold.

The crisis has caused a rapid increase in unemployment. In metropolitan France, the unemployment rate, as understood by the ILO, was at a relatively low level of $6.8 \%$ at the beginning of 2008 , without, in fact, showing that it was in the process of approaching a floor. The drop in economic activity had the mechanical effect of rising unemployment, which ended up exceeding $10 \%$. One of the criticisms to 
the functioning of the French labour market is its polarisation between insiders, holding permanent contracts, and outsiders, on fixed-term contracts or temporary jobs. Has the crisis widened this gap? Everything leads to think that companies first laid off workers with the least protection. Delphine Brochard and Corinne Perraudin offer a remarkable analysis of companies' behaviour. Their article shows that a much wider range of instruments than just the dismissal of outsiders was used to cope with the crisis. Thus, although a quarter of the establishments studied have reduced their workforce, nearly half of them also reorganised their activity, froze or decreased wages or resorted to short-time working. It is therefore not true to say that France has a preference for external adjustment, which would protect the insiders... It is particularly clear in the manufacturing sector, which was the most affected by the crisis, where the share of atypical employment does not seem correlated with workforce reduction. Unsurprisingly, the companies where social dialogue is the most active are also those who were able to combine various means of adjustment, including wage moderation, to cope with the crisis. In contrast, subcontractors and companies being majority foreign-owned were those where the decline in staff numbers was the most frequent, this leading to the obvious interpretation that decisions being made outside, social negotiation was also the least effective.

The crisis, whose tenth anniversary is marked by this special issue, has certainly made us understand a lot of new things but has most importantly made us rediscover old truths. The need for coordinated action from States, the decisive role of economic policy and the supervision of the financial system are simple ideas that had simply been forgotten. For economists, however, a huge amount of work remains to be done so that macroeconomic modelling draws all the lessons from it. Research has made significant efforts to integrate inequalities, financial markets imperfection, the dysfunctions of labour markets and agents' limited rationality, but it still lacks a canonical model able to include them into a coherent whole. It would be absurd to think that this work will provide the answer to the question that the Queen or her successor will ask during the next crisis, "Why didn't you see anything coming this time either?", but at least, we can hope that it will integrate the lessons of this crisis and allow a more brilliant response to the next one. 


\section{BIBLIOGRAPHY}

Barth, E., Bryson, A., Davis, J. C. \& Freeman, R. (2016). It's Where You Work: Increases in the Dispersion of Earnings across Establishments and Individuals in the United States. Journal of Labor Economics, Special Issue dedicated to Edward Lazear [Internet], 34(S2), S67-S97.

Blanchard, O., Cerutti, E. \& Summers, L. H. (2015). Inflation and activity-two explorations and their monetary policy implications. ECB forum on Central Banking, Sintra 21-23 mai 2015.

Blanchard, O. \& Leigh, D. (2013). Growth forecasts and fiscal multipliers, American Economic Review, 103(3), 117-120

Almunia, M., Benetrix, A., Eichengreen, B., O'Roorke, K. H. \& Rua, G. (2010). From Great Depression to Great Credit Crisis: similarities, differences and lessons. Economic Policy, 25(62), 219-265.

Piketty, T., Saez, E. \& Zucman, G. (2016). Distributional National Accounts: Methods and Estimates for the United States. NBER Working Paper No. 22945.

Ramey, V. \& Zubairy, S. (2014). Government Spending Multipliers in Good Times and in Bad: Evidence from US historical data. NBER Working Paper No. 20719. 